\title{
Education Values in Local Wisdom Awik-awik to Enviromental Conservation in Lombok Indonesia
}

\author{
Mohamad Liwa Irrubai \\ Department of Social Studies \\ UIN Mataram \\ Bandung, Indonesia \\ liwarubai@uinmataram.ac.id
}

\author{
Nana Supriatna \\ Department of Social Studies \\ Universitas Pendidikan Indonesia \\ Bandung, Indonesia \\ nanasup@upi.edu
}

\author{
Idrus Affandi \\ Department of Social Studies \\ Universitas Pendidikan Indonesia \\ Bandung, Indonesia \\ Idrus.affandi@upi.edu \\ Dede Rohaniawati \\ Department of Islamic Primary Education \\ UIN Sunan Gunung Djati \\ Bandung, Indonesia \\ dede.rohaniawati@uinsgd.ac.id
}

\begin{abstract}
This paper describes the education values on local wisdom Awik-awik Sesaot Village, Narmada District, West Lombok, West Nusa Tenggara and how the history of birth, content/material, implementation, and education values contained in the local wisdom Awik-awik Sesaot village. This research is a qualitative descriptive with ethnographic. The results show that Awik-awik was born based on the importance of preserving the forest and accompanied by improving the welfare of people around the forest. Therefore, in 1986 the Governor of NTB issued a decree no. 140 of 1986 on the use of coffee crops within the forest area in the NTB Provincial Level Region, the content of Awik-awik consists of advice, prohibitions, and sanctions, at the implementation stage involving all members of the community and the education values contained in Awik-awik consists of five basic values.
\end{abstract}

Keywords-education values; enviroment; forest conservation; local wisdom; lombok

\section{INTRODUCTION}

During this time, excessive forest exploitation continues to occur and disrupt the natural balance, for example, forest exploitation causes floods and landslides, forest clearing into new fields with forest burning have polluted the air in some areas in Sumatra, for example, Pekanbaru Riau and Jambi. In this case, Supriatna, explains that: "Exploitation of nature is a practice that departs from an anthropocentric point of view, is a view that puts human beings at the center of life in the earth. This view becomes a justification for humans to do hegemony as master of natural manager designer in order to be able to fulfill their life needs" [1]. This view also put aside the role of nature in regulating its balance so that its sustainability is intervened by human beings. As a result of this intervention, it is no wonder there is much damage that leads to natural.

An anthropocentric point of view is no longer relevant because humans are not simply controlling life on this planet. Further Supriatna, explains: "It needs a change of way from anthropocentrism to an ecocentric view that puts nature with all its contents as the center. Man is only part of nature and not the only factor that determines continuity or survival. In this view, man can not be separated from the realm where he lives" [1]. While Capra, revealed: "The need for a paradigm shift, namely that new concepts in Physics have brought about profound changes in our worldview; from the mechanistic worldview derived from Descartes and Newton into a holistic, ecological view. Holistic means viewing the world as a whole, while ecology means recognizing the fundamental interdependence of all phenomena and the fact that as individuals and our society are all embedded in (and absolutely dependent upon) the natural cycle process" [2]. Keraf in the analysis of environmental impacts with the holistic-ecological paradigm, "... must be comprehensive, i.e. social, cultural, moral (value), aesthetic and spiritual aspects" [3]. This means that people have not fully understood the consequences of their deeds because to meet the needs economics, then work by taking a shortcut or take an easy way to fulfill it i.e. for example by burning the forest regardless of the sustainability of nature. The reason for studying "traditional" society is because of the uniqueness of maintaining the way of dressing, speaking, politeness and the treatment of parents to children. Similarly, they retain the characteristics of the ancestors' way of life for thousands of years for their natural sustainability [4].

One of the strategies pursued to realize the sustainability of forest functions and roles is appropriate policy support through the implementation of forest management with an ecosystem approach. The management policy with ecosystem approach is a management policy that prioritizes the balance of ecosystems, where the management pattern is more process oriented that sees the diversity of forest forming elements.

\section{MethodOLOGY}

This research uses the qualitative methodology, ethnographic approach. This methodology is highly relevant to a very important research object in the local Awik-awik wisdom, in Sesaot Village Community, Narmada Sub District, West Lombok Regency, West Nusa Tenggara. The data collected were analyzed using the Miles and Huberman stages, namely: 1) 
Data Reduction, 2) Data Presentation (Data Display), 3) Taking Conclusion / Verification [5]. This study focuses on how the value of education contained in Awik-awik local wisdom and its impact on environmental conservation.

\section{RESULTS AND DISCUSSION}

\section{A. History and Implementaion of Awik-awik Sesaot Village}

According to Pujosewoyo: "Awik-awik Sesaot village is the whole law that regulates the way of life for indigenous villagers along with the sanctions and rules of implementation. Awik-awik comes from the word a means not and wik which means damaged, while awik means not damaged or good. Awik-awik means something that becomes good. This conception is poured into the rules both written and unwritten so that raises an understanding, that Awik-awik is the rules of life for the village in the village, to realize a safe, peaceful, orderly, and prosperous in a traditional village. Awik-awik it contains the basic rules relating to customary territory, customary village krama, religious and sanctions" [6]. Awik-awik Sesaot village was born from the local wisdom of the villagers, because they live around the forest sesaot, the pattern of these Awik-awik is the customary village regulations related to forest conservation, forest utilization containing the regulations on the suggestion, prohibition and sanction for violators, for the continuity of this Awik-awik bequeathed also hereditary.

Each village has its own local wisdom, according to the character of their residence. In Desa Sesaot, District Narmada, West Lombok District has a local wisdom called Awik-awik Desa. The following outlines some opinions on the concept of Awik-awik village. According Sirtha [7]: "Awik-awik Desa adat is a reflection of the soul of society, which is religious social. The philosophical foundation of Awik-awik traditional village is Tri Hita Karana (three sources of welfare), that is the human relationship with God Almighty, human relationship with a human, and human relation with its environment. Meanwhile, according to Jayadi and Soemarno [8], explained that the Awikawik village is a local wisdom in the form of customary rules (customary law). While Mukhtar, et al., [9] explains that, "Awikawik Desa is a local wisdom possessed by the people of Bali and Lombok which contains the values or norms that grow and develop, integrates with culture, beliefs expressed with myths and symbols, and inherited in a way hereditary". It can be seen that the concept Awik-awik Village comes from the teachings of the Hindu religion Tri Hita Karana (three sources of welfare), which contains advice, prohibitions, and sanctions for those who violate. This is reinforced by the concept presented by Mukhtar et al. that: "Awik-awik Desa is a local wisdom owned by the people of Bali and Lombok". If understood in terms of time and source of value in Awik-awik.

Village Awik-awik who came from Bali first existed from the teachings of Hinduism. While the value that existed in Awikawik Village in Lombok based on the value of living tradition from the experience of society from time to time. Thus, Awikawik Sesaot village was born from local traditions that live in rural communities, because they live in the vicinity of the Sesaot forest then the style of Awik-awik this is the customary village rules related to environmental conservation, especially the forest environment, the rules of daily interaction. The concept of Awikawik village is the rules or norms derived from the traditions that live in the community to maintain the environment, sociocultural and other forms of advice, bans, and sanctions are agreed upon and patterned in accordance with the place his stay, then for the continuity of this Awik-awik bequeathed to the next generation for generations.

Maintaining the preservation of forests and accompanied by improving the welfare of communities surrounding forests is the responsibility of the government and the community together. On this basis, in 1986 the Governor of NTB issued a decree no. 140 of 1986 on the utilization of coffee crops in forest areas in the province of West Nusa Tenggara Province. This decree was issued on the consideration that; first, in the NTB region, there are coffee plantation forest and coffee that grows itself in the forest. Secondly, to utilize the coffee plant as one of the sources of regional income can be collected maximally, it is necessary to regulate the management and utilization of a decision letter. Base on the decree mentioned above, to preserve the forest as well as benefit from the forest needed a local wisdom. The values of local wisdom in the community Sasak very suitable applied in life today and in the future, there is in the expression language that is held firmly in the association, the form of proverbs and proverbs as a social adhesive community Sasak In the community Sasak termed sekenggak. Sesenggak, the phrase language (traditional) in the form of proverbs and proverbs as a social adhesive community Sasak and environmental maintenance. In the teachings sesenggak much contained the teachings and traditional values/traditional wisdom, such as teaching about divinity, education, morals, law and so forth. With the awakening/awakening is born Awik-awik Sesaot village agreed and prepared by the community to maintain and preserve Sesaot forest.

TABLE I. CONTENT $A W I K-A W I K$ SESAOT ForeSt

\begin{tabular}{|c|c|}
\hline Aspect & Rule Edition \\
\hline $\begin{array}{l}\text { Recruitment of } \\
\text { Members }\end{array}$ & $\begin{array}{l}\text { Group membership comes from around the area } \\
\text { and is evidenced by a valid identity card or } \\
\text { certificate from the village government. }\end{array}$ \\
\hline Member Rights & $\begin{array}{l}\text { Entitled to collect NTFP in its cultivation } \\
\text { Entitled to develop incentives under standard } \\
\mathrm{Be} \text { entitled to a fair service from group } \\
\text { administrators } \\
\text { Be entitled to take decisions in meetings } \\
\text { Entitled to get access to loans from groups } \\
\text { Be entitled to vote and be elected to the board }\end{array}$ \\
\hline Member Obligations & $\begin{array}{l}\text { Maintain and maintain their lands from acts that } \\
\text { damage forest preservation, such as taking root } \\
\text { trees, cutting, burning and grabbing land } \\
\text { Protecting springs by multiplying the types of tree } \\
\text { stands that have conservation and economic value } \\
\text { around the water source points } \\
\text { Mutual respect with fellow members not to enter } \\
\text { each other and do not steal each other neighboring } \\
\text { plants. } \\
\text { Must pay group dues every year } \\
\text { Burning land that causes serious damage } \\
\text { Never pay the obligations in the form of } \\
\text { consecutive membership dues three times } \\
\text { Do not want to follow all the terms and rules that } \\
\text { have been agreed together in the form Awik-awik } \\
\text { Never want to attend any meetings organized by } \\
\text { the group for no apparent reason }\end{array}$ \\
\hline Member Dismissal & $\begin{array}{l}\text { Burning land that causes serious damage } \\
\text { Never pay the obligations in the form of } \\
\text { consecutive membership dues three times }\end{array}$ \\
\hline
\end{tabular}




\begin{tabular}{|c|c|}
\hline & $\begin{array}{l}\text { Do not want to follow all the terms and rules that } \\
\text { have been agreed together in the form Awik-awik } \\
\text { Never want to attend any meetings organized by } \\
\text { the group for no apparent reason }\end{array}$ \\
\hline $\begin{array}{l}\text { Requirements to be a } \\
\text { Group Administrator }\end{array}$ & $\begin{array}{l}\text { Group managers should come from group } \\
\text { members and own land in the group management } \\
\text { area } \\
\text { Minimum age } 25 \text { years and maximum } 60 \text { years for } \\
\text { still able } \\
\begin{array}{l}\text { Understand about the history of group } \\
\text { management }\end{array}\end{array}$ \\
\hline $\begin{array}{l}\text { Functions and } \\
\text { Authority of the } \\
\text { Management }\end{array}$ & $\begin{array}{l}\text { Coordinate all elements in groups and working } \\
\text { groups/blocks } \\
\text { Monitoring and evaluating and assisting all } \\
\text { working groups/blocks } \\
\text { Building relationships with outsiders in an effort } \\
\text { to strengthen groups and working groups/blocks }\end{array}$ \\
\hline Management Rights & $\begin{array}{l}\text { The board is entitled to incentives from the } \\
\text { group's efforts }\end{array}$ \\
\hline $\begin{array}{l}\text { Dismissal of the } \\
\text { Management }\end{array}$ & $\begin{array}{l}\text { Died } \\
\text { Own request } \\
\text { Move out of the area } \\
\text { Failure of duties and responsibilities } \\
\text { Use group finance or group name for personal } \\
\text { gain }\end{array}$ \\
\hline Board of Meeting & $\begin{array}{l}\text { Board meetings held at least } 3 \text { months } \\
\text { The board meeting is chaired by the chairman and } \\
\text { if the chairman is unable to attend the meeting, it } \\
\text { may be chaired by the vice chairman or secretary }\end{array}$ \\
\hline Membership Fee & $\begin{array}{l}\text { Cultivators of land are required to issue } \\
\text { membership dues every year based on the extent } \\
\text { of the cultivated area of Rp. } 1,000,-/ \text { are. } \\
\text { Contributions are paid by members during the } \\
\text { fruit season in March-August of the beginning of } \\
\text { the year }\end{array}$ \\
\hline Marketing Results & $\begin{array}{l}\text { Marketing of HHBK proceeds shall be done } \\
\text { through a group or business entity approved by the } \\
\text { group } \\
\text { The results of group-facilitated marketing are } \\
\text { entitled to a share based on mutually agreed } \\
\text { percentages. }\end{array}$ \\
\hline $\begin{array}{l}\text { Technical } \\
\text { Cultivation }\end{array}$ & $\begin{array}{l}\text { Plants planted in arable land with a composition } \\
\text { of } 30 \% \text { wood crops and } 70 \% \text { fruit plants } \\
\text { Plant maintenance is done by cleaning around the } \\
\text { stem } \\
\text { Using TTG } \\
\text { Fertilization with organic fertilizer }\end{array}$ \\
\hline Security Mechanism & $\begin{array}{l}\text { Cultivators must restrict their land by using living } \\
\text { fences } \\
\text { In a situation prone to tiller with the group to } \\
\text { patrol together with the group officials involving } \\
\text { the officers of the Forestry }\end{array}$ \\
\hline $\begin{array}{l}\text { Land Management } \\
\text { Rights }\end{array}$ & $\begin{array}{l}\text { Land management rights can be transferred only } \\
\text { to the heirs }\end{array}$ \\
\hline Neglect of Land & $\begin{array}{l}\text { Land neglect will be given successive warnings by } \\
\text { the group and if left unattended will be excluded } \\
\text { from the group membership and its field while the } \\
\text { group will be managed }\end{array}$ \\
\hline Burning Land & $\begin{array}{l}\text { Land-fired enforcement mechanisms will be } \\
\text { conducted by the group }\end{array}$ \\
\hline $\begin{array}{l}\text { Transfer of Land } \\
\text { Rights }\end{array}$ & $\begin{array}{l}\text { The transfer of under-handed land management } \\
\text { rights will be handled through group deliberations } \\
\text { to implement sanctions. }\end{array}$ \\
\hline Theft of Crops & $\begin{array}{l}\text { The theft of crops will be processed through group } \\
\text { meetings and the perpetrators will be given social } \\
\text { sanctions, can be in the form of circumference of } \\
\text { the village while covered by stolen plants and can } \\
\text { be in the form of material penalties for losses } \\
\text { incurred }\end{array}$ \\
\hline
\end{tabular}

a. Document Awik-awik Sesaot Village
The Awik-awik Awareness of Sesaot village was started in 1986 although Awik-awik is only a prohibition that is not allowed to cut timber and penetrate the forest. According to Ramite (Seséot Village elder) [10]: "We obey the awik on the basis of our awareness that the forest is not our right, but after being granted forest governance permit by the governor we only take the coffee beans according to the rules by the governor ". Subsequently, in 1996 the awa-awik of Sesaot Village was Awikawik consisting of 1) institutional, 2) Technical, and 3) Law enforcement / Awik- awik. More details can be found on the previous item research findings. This means that since 1996 Sesaot Village community has carried out awa-awik Sesaot Village inappropriate with mutual agreement. In 1996 the Awikawik institutional of Desa Sesaot was group management to coordinate forest managers consisting of: Responsible: Sesaot Village Head, Chairman: Masnun, Vice Chair: Darwite, and Secretary: Ramite.

While the board of the fifth period, in 2016 consists of: Responsible: Village Head Sesaot, Chairman: Sajai, Vice Chairman: Darwiah, Secretary: Ikliluddin, and Treasurer: Budiawan Haris. The functions and authority of the board are: a) Coordinate all elements in groups and working groups/blocks, b) Monitor and evaluate and assist all groups/blocks, and c) Build relationships with outsiders in an effort to strengthen groups and working groups/blocks. Implementation of Awik-awik that requires the patience of the board and the seriousness of group members to be implemented is on the mechanism of securing the area so as not to occur the theft of timber and logging of a forest. Darwiah (group vice chairman) explains that: "Group members should cooperate in the security of the management lands, in the event of the theft of plants and timber to report to the head of the group in order to take action in accordance with the prevailing rules/Awik-awik" [11]. For members of the group's willingness and patience to continue to nurture the group is a pride because the members of the group become mutually respectful with the board and with other group members, so Awik-awik run with awareness for personal interests and groups broadly.

The statement is in accordance with the function Awik-awik adat village, is a customary law that has a function to regulate and control the behavior of citizens in order to achieve order and peace of society. In addition, according to the MPLA of Bali [12]: Awik-awik also serves as a binder of unity and unity of krama village to ensure cohesiveness and integrity in unifying common goal to realize a safe, orderly life, and prosperous in customary village areas. Jayadi and Soemarno [8] explained that "As a people's law used to regulate people's lives, customary law constantly changes. The changes are attributed to strengthening capacity through the strengthening of the structure and function Awik-awik. The strengthening is done by issuing village regulations as a container to accommodate new changes that were not previously included in the old Awik-awik. The heaviest task is carried out by the local Awik-awik (Judges and watchdogs Awik-awik) that oversees the implementation of Awik-awik when solving the problem Awik-awik when a violation. Mr. Sajai (Chairman of the Group) explains that: "Mr. Darwite as Loka Awik-awik has been edited in January 2017, so the affairs of Loka Awik-awik are temporarily handled by the group leader with Sesaot Village Head. 2016 were the theft of crops by one 
of the members and timber theft" [13]. The mentioned awful offenses are:

- The neglect of land by two members, by loka Awik-awik given sanction, revoked his rights governance and returned to the head of the group to be given to new members.

- Theft of crops by a member and caught. By loka Awikawik given sanctions return the goods stolen and pay a fine.

- Theft of a log by an outsider and caught. By loka Awikawik gave sanctions restore stolen timber and pay a fine.

The awful offense that is still illegal logging by people outside the area, this is due to the limited number of members of the forest security and members to keep the land under management at night because the residence is far at least 3 kilometers from managing land. In awik-awik it is also arranged that members should not stay within the forest/forest lands. However, in the event of massive timber and large-scale thefts will be patrolled along with forest protection with the group members in turns.

\section{B. Education Values Contained to Awik-awik Sesaot Village}

The education values of local wisdom Awik-awik Sesaot Village in forest preservation can be seen in the chart below:

TABLE II. EDUCATION VALUES OF AWIK-AWIK

\begin{tabular}{|l|l|l|}
\hline Local Wisdom & \multicolumn{1}{|c|}{$\begin{array}{c}\text { The Implementation of Awik- } \\
\text { awik }\end{array}$} & $\begin{array}{c}\text { Educational } \\
\text { Values }\end{array}$ \\
\hline $\begin{array}{l}\text { Aiqmeneng, } \\
\text { tunjungtilah, } \\
\text { empaq bau } \\
\text { besesiru/besiru }\end{array}$ & $\begin{array}{l}\text { Uphold the deliberations in } \\
\text { making rules and solving } \\
\text { problems }\end{array}$ & Help each other \\
\hline $\begin{array}{l}\text { Bau Besi, Bau } \\
\text { Asaq }\end{array}$ & Environmental conservation \\
\hline $\begin{array}{l}\text { Ndaq tame } \\
\text { gawah laun } \\
\text { ketemuq siq jin }\end{array}$ & Keep the springs up & Responsible \\
\hline $\begin{array}{l}\text { Ndaq bait doen } \\
\text { dengan laun } \\
\text { cekok }\end{array}$ & $\begin{array}{l}\text { Obey the Awik-awik/ regulations } \\
\text { that have been agreed }\end{array}$ & $\begin{array}{l}\text { Life } \\
\text { sparingly/simpl } \\
\text { e }\end{array}$ \\
\hline
\end{tabular}

The meaning of each education values can be explained as follows:

- Aiq meneng, tunjung tilah, empaq bau: meaning that in overcoming and resolve a dispute, strived to keep the atmosphere calm, people do not panic, problems or disputes resolved peacefully through deliberation / consensus).

- Besesiru/besiru that is the value of local wisdom is also almost the same as sauralap (mutual help in cultivating rice fields, as in ngekiskis / cleaning grass with cutting tools kikis or ngoma / ngome / weed grass, the work "gotong royong" work in the fields from planting seeds to harvest.

- Bau Besi, Bau Asaq. It means that a high sense of responsibility and balance is needed to achieve our expectations or desires, such as the benefits of forests obtained, as well as forests sustainability.

- Ndaq tame gawah laun ketemuq siq jin, meaning banned entry and forest to be kept from the catastrophe, the depletion of wood, the occurrence of landslides and depletion of springs. This expression teaches to live frugally and simply.

- Ndaq bait doen dengan laun cekoq, that is prohibited to steal because it will result in the depletion of possessions that we have and get sin according to religious teachings. In many ways humans are taught to be honest both working for themselves and others.

\section{CONCLUSION}

Awik-awik Sesaot Village is a regulation that was born from local wisdom of Sesaot village, then compiled and written to become a regulation that can be read, understood and implemented by all Sesaot Village community responsibly in the conservation of sesaot forest environment in particular and society as a whole in general. their adherence to Awik-awik that was born from local wisdom of the local community, all of which implies that the values held by the community will always live and even grow into a source of regulation that always gives keselarsan and harmony of community life under the pressure globalization and modernization in all fields. Furthermore, how Awik-awik is inherited by parents to the younger generation who will live in his time to always take care of local wisdom and they can have a filter from the negative influence of the times.

\section{ACKNOWLEDGMENTS}

Thanks to the head of the village and the people of the district of Lobar Nusa Southeast, Lombok Indonesia and the head of junior high school 5 Narmada Lobar, the principal of junior high school 4 and 16 Mataram.

\section{REFERENCES}

[1] N. Supriatna, Ecopedagogy, Membangun Kecerdasan Ekologis dalam Pembelajaran IPS. Bandung: PT. Remaja Rosda Karya, 2016, p. 106.

[2] F. Capra, The New Vision of Epistimology and Life. Yogyakarta: Fajar Pustaka Baru. 2002, p. 14.

[3] A.S. Keraf, Environmental Ethics, Jakarta: Gramedia, 2010, p. 354.

[4] J. Diamond, The World Until Yesterday (What We Can Learn from Traditional Communities), Jakarta: Kepustakaan Populer Gramedia. 2015 , p. 8.

[5] M.B. Miles, and A.M. Huberman, Qualitative Data Analysis, Sage Publication, 1994.

[6] K. Pujosewoyo, Guidelines for Indonesian Legal Literature, Jakarta: Universitas Indonesia, 1983

[7] I.M. Titib, Ajeg Bali Dialogue Perspective of Hinduism, Surabaya: Paramita, 2006, p. 120.

[8] E.M. Jayadi, and Soemarno, "Analysis of Awig-Awig Transformation in Indigenous Forest Management (Case Study In Wetu Telu Community in Bayan Region, North Lombok)," Indonesian Green Technology Journal, 2nd ed, vol. 2, p. 39-51, 2014.

[9] Mukhtar, et. al., "Community Forest Management on the basis of Local Wisdom: A Case Study in The Protection Forest of Sesaot, Western Lombok," 1st ed., Indonesia: Jurnal Wawasan, vol. 13, p. 132-151, 2016.

[10] Ramite, interview, 2017, 25th April.

[11] Darwiah, interview, 2017, 24th, March. 
[12] Assembly of Indigenous Institutions (MPLA) Lever 1 Bali, "The Role of Indigenous and Cultural Values in Supporting Development, Project for Consolidation of Customary Institutions” Denpasar, 1988, unpublished.

[13] Sajai, Interview, 2017, 24th March. 